\title{
ІСТОРИЧНИЙ НАРИС ДОСЛІДЖЕНЬ ПРОБЛЕМАТИКИ ОСОБИСТІСНОЇ СВОБОДИ У ПСИХОЛОГІЧНІЙ НАУЦІ: ГУМАНІСТИЧНА ПАРАДИГМА
}

Стаття присвячена аналізу сучасних теоретичних досліджень проблематики особистісної свободи в психології. Прослідковується формування наукових уявлень про особистісну свободу серед українських вчених та виокремлення иієї інформації в самостійну наукову проблему в сучасній украӥнській психології. Особистісна свобода розглядається у площині саморозвитку та самореалізації, виступає иентральним утворенням духовності особистості. Основною ознакою особистісної свободи є здатність здійснювати конструктивний вибір і нести відповідальність за його наслідки, керуватись совістю при здійсненні изього вибору.

Ключові слова: свобода, особистість, вибір, духовність, особистісна свобода.

The article deals with the analysis of the modern approaches to the problem of personality in psychology. The phenomenon of individual freedom and the dynamics of views at the problem of internal freedom of a person are investigated in this work in Ukrainian sciences. Isolating this information into an independent scientific problem in modern Ukrainian psychology. Personal freedom is considered in the plane of self-development and self-realization, acts as the central form of the spirituality of the individual. The main feature of personal freedom is the ability to make a constructive choice and to bear responsibility for its consequences, to be guided by conscience in the exercise of this choice.

Keywords: personality, individual freedom, creative, spiritual, personality freedom.

Постановка проблеми. В українській психології особистісну свободу як самостійне соціально-психологічне явище почали вивчати порівняно недавно. На сьогоднішній день серед українських дослідників немає єдиного підходу до цієї проблеми. Часто ця категорія виступає синонімом внутрішньої, позитивної, психологічної або духовної свободи. Окрім того, не існує чіткої класифікації видів свободи та єдино визначеного тлумачення їх змісту. А тому метою повідомлення $\epsilon$ історичний огляд дослідження того аспекту феномену свободи, що функціонує на рівні особистості для того, щоб окреслити проблематику дослідження і сформувати інформаційну базу для подальших розробок.

Виклад основних положень. Проблематика свободи особистості $\epsilon$ міждисциплінарною і в психологічній науці чітко окреслилась як самостійний напрям досліджень порівняно недавно. Тому перш ніж приступати до вивчення цієї теми в сучасній українськй психології, варто звернутися і до іншого спектру наук гуманістичного спрямування. Вихідні положення проблематики свободи знаходяться в системі антропологічних наук. Так, свобода в етиці постає як здатність вільно визначати підстави своїх дій та відповідно реалізовувати себе; як свобода волі, що є здатністю суб'єкта вільно визначати сутнісні підстави власного воління; як своєрідна похідна від волі, що уможливлює морально(C) Лукеча I., 2018. 
етичну значущість останньої; як свобода совісті, що являє собою одну з фундаментальних, загальнолюдських цінностей, що постає як суспільний феномен $\mathrm{i}$ перебуває у нерозривному зв'язку із сенсом, світоглядними координатами буття людини [12, с. 570-572]. Свобода з цих позицій трактується як якісно особливий стан моральної свідомості, що включає в себе здатність вільно здійснювати духовно-ціннісний, світоглядний, реалізовувати себе згідно свого вибору і пошуку сенсу життя, а також нести автентичну відповідальність за все це.

Поняття свободи у філософії визначається як особливий спосіб детермінації духовної реальності, котра безпосередньо виявляє себе у людській життєдіяльності, що становить взаємодію духовних (свідомих і несвідомих) та природних (тілесно-біологічних) чинників. Тому свобода з філософських позицій $\epsilon$ насамперед усвідомленням можливісних меж людської поведінки, які залежать від конкретної ситуації людського існування і в цьому плані являють собою усвідомлену необхідність. Атрибутивними ознаками свободи як духовного феномена є автентично-екзистенційний вибір і відповідальність.

Найбільше уваги вивченню проблеми свободи у філософії присвятили М. Бердяєв, Г. Гегель, І. Кант, І. Ільїн, Ж.-П. Сартр, Б. Спіноза та ін. На їх думку, свобода притаманна лише особистості. Втрачаючи свободу, піддаючись полону пристрасті особистість втрачає саму себе і стає рабою гріха.

Існує декілька диференціацій видів свободи у філософії. Так, М. Бердяєв розрізняв «свободу від» відповідальності як повстання та відчуження від Бога, вседозволеність та «свободу для» відновлення втраченого внаслідок гріхопадіння зв'язку з Богом. У найвищому сенсі вільною є лише та частина людської природи, яка з'єднана з Божою [3, с. 151-156]. Відтак першопочаткова свобода - у виборі між добром і злом, а кінцева - у Істині, Добрі та Красі. Другий вид свободи означає звільнення себе від низьких душевних стихій, від влади пристрастей - людина на цьому рівні перестає бути рабом самого себе та оточуючого світу. Лише християнство, на думку М. Бердяєва, дає людині таку свободу, а особистість, яка оволоділа цією свободою, називає «вдруге, духовно народженою» [2, с. 421-424]. Свавілля та свобода, за якої суб'єкт не хоче знати нічого вищого, ніж задоволення пристрастей є рабством самої себе. Коли ж «людська свобода 3'єднується 3 божественною свободою, людський образ - із Божим», тоді досягається справжній «внутрішній досвід свободи», який необхідний для становлення Боголюдини [2, с. 426].

Ряд авторів виокремлюють зовнішню свободу, як непідкореність зовнішнім діям і внутрішню свободу, як буття із самого себе, свободу само здійснення, як внутрішню необхідність визначення самого себе. Зовнішня свобода дається людині для внутрішнього звільнення. За своєю суттю другий вид свободи є духовною категорією. Лише духу притаманна здатність внутрішньо звільняти себе, самопідсилюватись та самовизначатись до блага. Звільнити себе - це, перш за все, повернути собі всю силу, щоб стати сильнішим за будь-який потяг, примху, бажання, спокусу, гріх. Але це - лише перший етап самозвільнення, другий же полягає у добровільному заповненні себе кращими, вибраними й улюбленими життєвими смислами. Звільнити себе - це значить стати волода- 
рем своїх пристрастей: не затиснути їх у собі, а духовно облагородити i перетворити [9, с. $194 ; 4$, с. 136-158].

Класифікацію свободи розробив відомий український філософ В. І. Шинкарук та виокремив:

1) квазісвободу, яка є лише формальною; поділяється на фаталістичну, де людина цілковито керується необхідністю, і контингентну, що розуміється як випадковість або сваволя, де відсутній особистісний вибір;

2) емпіричну свободу, яка базується на вольовому виборі котроїсь із кількох нерівноцінних можливостей, та є реальною, а тому й відповідальною;

3) екзистенційну свободу, яка угрунтована у найглибшій суті людського існування, яка є безпосередньою демонстрацією духовної реальності, не обтяженої перетвореною формою раціональності. Вона базується на виборі ще не існуючих можливостей, а тому вимагає їх попереднього творення. Особистість, яка володіє такою свободою несе тягар відповідальності за увесь Всесвіт [12, c. 570-572].

Спираючись на філософські трактування сутності свободи, психологи вивчають іï феноменологію на синергетично-системному рівні своєї науки - особистісному (персонологічному). Найвищі досягнення у цій сфері персонології містить, на нашу думку, вершинно-психологічна теорія логотерапії В. Е. Франкла. Людина, згідно з В. Е. Франклом, не може здобути цілковитої свободи, оскільки детермінована біологічними, і психологічними, і соціальними чинниками, проте вона є вільною у своєму ставленні до цих детермінацій. І людський вимір існування полягає саме в тому, щоб автентично долати ці обмеження, підніматися над умовностями життя, не коритися владі обставин, а розуміти, що останні підкоряються рішенню особистості. Долаючи рівень психофізіологічної даності, людина має змогу звертатися до власної сутності і при цьому не протистояти їй - це вихід за межі самого себе і можливість «бути співприсутнім іншому сутньому», а отже пізнати його і полюбити. Саме в цьому, на думку В. Франкла, полягає існування людини і саме це є змістом духовної реальності, а духовне і є вільне у людині [13, с. 77-78, 112].

Тобто, В. Франкл вважає, що людина є вільною у своєму духовному налаштуванні, яка полягає у можливості автентично ставитись до обставин свого життя, і виокремлює свободу у налаштуваннях стосовно потягів, спадковості та середовища, підкреслюючи, що потяги є у владі людської духовності і дух здатен цілковито контролювати їх. Прийняти і реалізувати свій потяг, чи відмежуватися від нього цілком, залежить від самої особистості та їі духовного начала. Свобода стосовно спадковості полягає у можливості вільно застосовувати власні здібності та задатки - розвинути їх чи ні, спрямувати у позитивне чи негативне русло (на творчість і благо, чи на злочини та руйнацію). Що стосується середовища, то його вплив на людину також не є вирішальним - все залежить від того, яку якість, рису характеру чи спосіб поведінки особистість проявить в певних життєвих обставинах, спрямує себе - до духовних цінностей чи проявить примітивні тваринні інстинкти. Узагальнюючи вищесказане, В. Франкл підсумовує, що будь-яке налаштування в першу чергу залежить від особис- 
тісної позиції людини, їі вільної автентичної основи для прийняття рішення. I саме завдяки цій свободі особистісної позиції можливою стає екзистенційна перебудова всієї людини, яка полягає у свободі бути іншою, протистояти, заперечити своїм психофізіологічним детермінантам, вийти за межі самої себе тощо $[13$, c. 111$]$.

Ця особистісна позиція $є$ вирішальною. Завдяки їй духовна особистість приймає рішення про те якою їй бути. А будь-яке рішення, на думку В. Е. Франкла, - це завжди формування себе, свого характеру, своєї долі. В цьому полягає свобода діяти згідно зі своєю сутністю, а також можливість зміни особистості відповідно до свого вчинку: людина не лише чинить у відповідності з тим, чим вона $\epsilon$, а й формується відповідно до того як вона чинить. Так, постійне творення добра формує у людини якість доброчинності, а постійне, переведене уже в звичку, моральне діяння врешті-решт стає моральною позицією особистості. А тому кожен сьогоднішній вибір у майбутньому може стати особистісною необхідністю [13, с. 113-114].

Отже, в основі свободи особистості, за В. Е. Франклом, лежить ії особистісна позиція, яка є визначальною для формування та самоздійснення, але формують цю позицію автентичні вибір і безпосередньо вчинок. Моральні вибори та вчинки приводять до формування моральної позиції, аморальні - до аморальної і т. ін. У зв'язку з цим В. Е. Франкл вирішальне місце відводить відповідальності особистості, яку вважає позитивним аспектом свободи: «Свобода може виродитися у звичайнісіньку вседозволеність, якщо вона не проживається 3 точки зору відповідальності» [13, с. 88]. Людина повинна нести відповідальність за своє буття, а це є можливим лише за наявності у неї сенсу життя, логосу. Інстанцією, перед якою особистість несе відповідальність і перед лицем якої приймає рішення є совість. Совість, на думку В. Франкла, - це трансцендентна божественна над-особистість, яка стоїть за людським «над-Я». «Розмова із совістю - це особливі близькі особистісні стосунки людини і Бога, які носять діалогічний характер» $[13$, с. 126]. I саме можливість жити у злагоді з совістю, згідно з ії імперативами дарує особистості переживання істинної свободи. Таким чином, свобода, за В. Е. Франклом, полягає у можливості подолання власної психофізіологічної та соціологічної детермінації, шляхом особистісного налаштування щодо неї, а також у необхідності нести відповідальність за кожне особистісне рішення та вчинок, перед своєю совістю.

Поділяючи ідеї В. Е. Франкла, В. П. Москалець вважає, що свобода є духовним феноменом, за допомогою якого особистість здатна здійснювати вибір ствердження чи заперечення зовнішніх стимулів і внутрішніх потягів, попередньо провівши їх диференціацію та співставлення із духовними цінностями. За допомогою автентичної свободи особистість спроможна долати в собі негативні потяги, «ошляхетнювати біологічне та соціальне в диспозиціях, поведінці та діяльності». Це здатність автентично визначати сенс, ціннісні орієнтації, норми свого життя. Автентична свобода, виявляється, $є$ неможливою без екзистенційної відповідальності особистості, яка $є$ істотною складовою ï духовності і ви- 
значається наявністю у суб’єкта автентичних смислів та цінностей [10, с. 75, 147].

Стрижневою функціональною структурою духовності особистості, яка відіграє важливу роль у формуванні екзистенційної відповідальності та свободи, $\epsilon$ моральність. Вона виступає автентичним регулятором поведінки та світогляду індивіда і здійснюється за допомогою совісті. Саме совість допомагає суб'єкту відрізнити добро від зла [10, с. 75]. Роблячи вибір згідно своєї совісті, особистість розвиває автентичну свободу та формує позитивну вершину акме. Стверджуючи добро, особистість входить у духовний світ, в якому діють ті ж закони, які вона підтримує: «Чини з іншими так, як хочеш, щоби поводилися 3 тобою». Так, наприклад, проявляючи чуйність, чесність, доброту, милосердя тощо, особистість і в інших людях буде помічати ці ж якості. I, навпаки, проявляючи байдужість, хитрість, заздрість, обман тощо, вона щоразу буде стикатися з такими ж негативними проявами в оточуючих.

Автентична свобода полягає у виборі світу, у якому вирішує жити особистість - ствердження вищих духовних цінностей добра, чи приземлених тваринних потягів або ж негативних проявів особистості. «Стале, непохитне автентичне прагнення робити добро, не чинити зла, бути доброчинною, альтруїстичною формується в особистості внаслідок почування органічного, нерозривного, іманентного зв’язку з Творцем і Його творінням» [10, с. 84]. Відсутність такого зв'язку викликає в особистості екзистенційний вакуум, відчуття абсурдності існування, нівелює екзистенційну відповідальність та відкриває перед особистістю шлях свавілля, вседозволеності та відчуття безкарності. Людина починає реалізовувати свободу від Бога, вона стає вільною від Бога, тобто «божевільною» цим самим втрачаючи зв'язок із власною совістю, автентичним світом та віддаляється від автентичної свободи.

Проте цей зв’язок не передбачає сліпої фанатичної релігійної віри, а, навпаки, розум повинен бути тверезим і ясним, людина має чітко усвідомлювати як свою безсилість перед труднощами світу та існування, так і свою перевагу за рахунок віри у вершинні смисли існування. Це мужність прийняти екзистенційний відчай, породжений усвідомленням безсилля людини в світі, і попри все це знаходитися у пошуку та устремлінні до вищого вершинного смислу свого життя. Автентична свобода вбачається тут у силі духу протистояти байдужості та раціональності світу і попри все спрямовувати себе до вищих екзистенціалів, таких як Добро, Любов, Дружба, Краса тощо, переживаючи при цьому ще й духовну насолоду. Саме у такому бунті проти абсурдності світу і проявляється «вільний високий злет людського духу», а це і є здійснення автентичної свободи [10, с. 82-84].

3 позиції звільнення від зовнішньої детермінації розглядає свободу Д. О. Леонтьєв і вважає, що свобода феноменологічно являє собою певний базовий стан, що стосується більшою мірою можливості, ніж власне акту здійснення конкретної події. На його думку, свобода - це можливість ініціації, зміни або припинення суб'єктом своєї діяльності в будь-якій точці їі перебігу, а також відмови від неї. Свобода передбачає можливість подолання тих форм і видів 
детермінації активності особистості, що виступають як зовнішні щодо дієвого екзистенційного «Я»- у тому числі власних налаштувань, стереотипів, сценаріїв, рис характеру і психодинамічних комплексів [7, с. 17-22].

Д. О. Леонтьєв виокремлює ключові аспекти проблематики свободи, які можна охарактеризувати такими тезами:

1) свобода полягає у сходженні на вищий рівень регуляції, що робить людину вільною від багатьох видів детермінації, проте не всіх;

2) момент вибору, який має за основу лише власне усвідомлене рішення це розрив детермінації;

3) усвідомлення наявних можливостей і потенціалів, а також уміння відсторонитися від ситуації, що веде до суттєвого зростання рівня свободи і допомагає побачити більше можливостей та шансів активної зміни ситуації в потрібному напрямку;

4) сукупність зовнішніх (ситуаційних), внутрішніх (особистісних) та проміжних між ними (соціальних та матеріальних) ресурсів визначає ступінь свободи суб'єкта в певній ситуації;

5) свобода неможлива без її ціннісно-смислового обгрунтування, яке певним чином обмежує та перешкоджає їі виродженню у вседозволеність [7, с. 22-24].

Д. О. Леонтьєв вважає, що більшість людей, «утікаючи від свободи», втікають насамперед від відповідальності; а оскільки відповідальність - це характеристика особистості, то вони «втікають і від особистості». Причиною цього $\epsilon$ неправильне розуміння поняття особистості, яке часто плутають з набором індивідуальних особливостей, чим насправді $є$ індивідуальність. Суттю ж особистості, на думку автора, $\epsilon$ те, як людина будує свої стосунки зі світом, керуючись при цьому логікою смислу та життєвих стосунків, а на ії найвищому рівні розвитку - логікою свободи вибору. I кожна людина стає особистістю настільки, наскільки перетворює свою індивідуальність.

Особистісний розвиток - це насамперед самостановлення, активний процес, пов'язаний не 3 пасивним очікуванням дозрівання чогось, а з активною роботою. Лише особистими зусиллями породжується еволюція, а бездіяльність призводить до занепаду. I лише власними зусиллями народжується свобода. Як тільки ми послаблюємо зусилля, вона перестає існувати [8, с. 20-25]. Отже, свобода, за Д. О. Леонтьєвим, є динамічним процесом, - понад це, вона твориться устремлінням та вольовими зусиллями.

Автор виокремлює такі різновиди свободи:

1) «свобода від»- це відсутність зовнішніх обмежень і примусів діяти певним чином, що сковують життя людини;

2) «свобода для» - це психологічна позиція, як ціннісне обгрунтування, що, здавалось би, обмежує свободу людини, проте насправді дає істинне розуміння суті речей, істинне знання [7, с. 17].

Окрім «свободи від» та «свободи для», Д. О. Леонтьєв виокремлює ще й екзистенційну свободу, з якою людина стикається на найвищих рівнях регуляції. А найвищий рівень регуляції - це рівень, на якому вона приймає рішення відповідно до суті речей. Цей вибір добровільний, але не стихійний, бо суть ре- 
чей - не стихійна, а імперативна. Людина приймає вільне рішення орієнтуватися на неї, робити те, що вимагає суть речей. I в цьому - свобода вибору, тому що людина не зобов'язана цього робити, вона може жити, як і раніше, і не вникати в суть речей. Але якщо особистість уже прийшла до розуміння суті речей, вона добровільно підпорядковує свій шлях новому, вищому регулятивному імперативу, добровільно несе свій хрест, як Христос та інші просвітлені представники людства - «homo transcendence» - ті, що глибоко пізнали суть речей. Інакше кажучи, чим більше у людини свободи, тим менше у неї вибору [8, c. 23-27]. Можна сказати, що вищий рівень свободи є добровільним рабством, але не в зовнішньому світі, а в духовному, який відкриває перед людиною суть речей, після чого вже неможливо діяти всупереч цим істинам.

Отже свобода, за Д. О. Леонтьєвим, є динамічним процесом, який породжується особистими вольовими зусиллями та устремлінням, що проявляються як вибір; вона полягає в особистісному становленні (підняття на вищий рівень регуляціï); їі міра залежить від усвідомлення потенцій та правильного використання ресурсів, які надає ситуація, і які є в наявності у людини, а тому вона потребує ціннісно-смислового обгрунтування. Найвищий рівень свободи є добровільним підкоренням вищим духовним імперативам і полягає у розчиненні вибору, оскільки особистість всім своїм єством приймає духовний світ Добра i лише щоразу підтверджує своїм життям остаточно зроблений екзистенційний вибір.

О. С. Анісімов також розуміє свободу як звільнення від зовнішньої детермінації при збереженні залежності від внутрішніх факторів буття. Таке розуміння свободи, на його думку, знімає суперечність і контраст між внутрішнім та зовнішнім, свободою і необхідністю. Отримуючи потенціал зовнішньої свободи, людина також одержує потенціал нанесення шкоди (руйнації) цілісності організму, навколишньому середовищу. Щоб не зашкодити їм, необхідний механізм позитивного використання свободи, який базується на принципі цілісності та принципі служіння Універсуму [1, с. 45].

Отже, щоб уникнути протистояння зовнішньої та внутрішньої свободи, людина повинна у своїй зовнішній діяльності орієнтуватися на духовні цінності та внутрішні істини, підпорядковуватися голосу власної совісті, що проявляється як служіння Вищому Смислу.

Як звільнення від залежностей розуміє свободу і К. Сельчонок та вважає, що особистісно вільна людина - це та, яка звільнилася від пут тих чи інших залежностей. Залежність - це певна форма рабства, гріх або захворювання душі. Вона стає перепоною на шляху людини до повноти самореалізації, яка називається щастям. А внутрішня свобода виступає як можливість знаходження нових, більш ефективніших шляхів своєї самореалізації [11].

Автор розрізняє свободу душевну, психологічну або особистісну, які він ототожнює, а також свободу творчості та духовну. Особистісна (психологічна або душевна) свобода визначається як звільнення від залежностей. Основне рішення щодо іiі здобуття лежить у духовній сфері. Духовність людини полягає у прийнятті життєстверджуючого рішення бути якомога більш вільним, щасли- 
вим і радісним для себе та для інших. При цьому для здобуття справжньої свободи від залежності потрібно не лише прийняти рішення про трансформацію всього свого життя, а й переглянути, здійснити системний глибинний аналіз усіх власних звичок, очікувань та ставлень, переконань і мотивів, а також змінити способи взаємодії 3 іншими людьми та узвичаєні типи реагування на життєві ситуації - тобто перепрограмувати власну психіку та прилучитися до нового, здорового стилю життя [11].

Свободу, як можливість обирати способи дій у житті, виокремлює і Р. Кочюнас та називає іiі свободою вчинку (термін увів В. Франкл). Також дослідник визначає сутнісну свободу (термін увів Р. Мей) як можливість обирати власну позицію щодо когось або чогось. Саме сутнісна свобода $\epsilon$ основою людської гідності, оскільки зберігається за будь-яких обмежень і залежить не стільки від зовнішніх обставин, скільки від внутрішньої налаштованості. Вона пов'язана 3 умінням бачити парадоксальність оточуючого світу та наших переживань. Проте, якою б свободою ми не володіли, вона ніколи не буде гарантією, - лише шансом для здійснення наших життєвих планів [6]. Тобто, свобода дає перспективу для власної реалізації, але не ототожнюється 3 нею. Вона є умовою найповнішого саморозкриття та самоздійснення особистості.

3. С. Карпенко вважає, що абсолютна духовна свобода проявляється станом прийняття Благодаті, як повнота переживання своєї єдності з Космосом i внутрішньої гармонії. Верховною цінністю людської екзистенції є благо як позитивний зміст буття взагалі. А відчуття благодаті переживається як поклик запрошення реалізувати своє покликання, відбутися як особистість, що сповняє власне - унікальне, незамінне призначення у світі [5, с. 71-73].

Свободу волі дослідниця розглядає як сутнісне визначення особистості в якості духовного суб'єкта, як благодать Божу, що супроводжується величезним тягарем відповідальності за наслідки свого ціннісного самовизначення. Дилема свободи вибору і тягаря відповідальності вирішується за допомогою поглиблення, збагачення та розширення ціннісно-смислової свідомості особистості. «Добру чи злу сутність людини визначає їі життєве середовище смислоутвердження, мірилом якого виступає гідність і совість конкретної людини, іiі готовність перед лицем Абсолютної Досконалості тримати звіт за результати самореалізації, усвідомлення свого сенсу існування та виконання свого життєвого покликання» [5, с. 61-62].

Висновки. Отже, можемо зауважити, що особистісна свобода у психологічній науці розглядається у площині саморозвитку та самореалізації та виступає центральним утворенням духовності особистості. В іiі основі лежить здатність здійснювати конструктивний вибір і нести відповідальність за його наслідки. Совість особистості є регулятором, яким керується особистісно вільна людина. А сміливість прийняти труднощі, 3 якими особистість стикається на життєвому шляху і попри все спрямовувати себе до прояву та утвердження духовних імперативів є істинним проявом особистісної свободи.

1. Анисимов О. С. О воле и «свободе воли». Мир психологии. 2007. № 3 (51). С. 36-46.

2. Бердяев Н. А. Смысл творчества. Харьков : Фолио ; Москва : Изд-во АСТ, 2002. 688 с. 
3. Бердяев Н. А. Философия свободы. Харьков : Фолио ; Москва : Изд-во АСТ, 2002. 624 с.

4. Ильин И. А. Религиозный смысл философии. Москва, 2003. 694 [10] с.

5. Карпенко 3. С. Аксіопсихологія особистості. Київ, 1998. 216 с.

6. Кочюнас P. Свобода и психотерапия URL: mailto:rimask@parkas.It (дата звернення: 03.05.2011).

7. Леонтьев Д. А. Психология свободы: к постановке проблемы самодетерминации личности. Психологический журнал. 2000. Т. 21. № 1. С. 15-25.

8. Леонтьев Д. А. Симбиоз и адаптация или автономия и трансценденция. Выбор личности в непредсказуемом мире. Личность в современном мире : от стратегии выживания к стратегии жизнетворчества / ред. Е. И. Яцута. Кемерово : Графика, 2002. С. 3-34.

9. Мень А. В. У врат Молчания. История религии : В поисках Пути, Истины и Жизни : в 7 т. Москва : Слово, 1992-1994. 239 с.

10. Москалець В. П. Духовні горизонти особистості: потенціал вершинної аналітики. Психологія і суспільство : Украӥнський теоретико-методологічний соціогуманітарний часоnuс. 2011. № 1. С. 96-108.

11. Сельченок К. От зависимости - к духовной свободе URL: sky@aquarun.ru (дата звернення 26.02.2012).

12. Філософський енциклопедичний словник / ред. В. І. Шинкарук. Київ : Абрис, 2002. 742 с.

13. Франкл В. Человек в поисках смысла. Москва : Прогресс, 1990. 368 с. 